Relations industrielles

Industrial Relations

\title{
Godard, John, Industrial Relations: The Economy and Society
}

\section{Kurt Wetzel}

Volume 50, numéro 3, 1995

URI : https://id.erudit.org/iderudit/051040ar

DOI : https://doi.org/10.7202/051040ar

Aller au sommaire du numéro

\section{Éditeur(s)}

Département des relations industrielles de l'Université Laval

\section{ISSN}

0034-379X (imprimé)

1703-8138 (numérique)

Découvrir la revue

Citer ce compte rendu

Wetzel, K. (1995). Compte rendu de [Godard, John, Industrial Relations: The Economy and Society]. Relations industrielles / Industrial Relations, 50(3), 659-660. https://doi.org/10.7202/051040ar

Tous droits réservés (C) Département des relations industrielles de l'Université Laval, 1995
Ce document est protégé par la loi sur le droit d'auteur. L’utilisation des services d'Érudit (y compris la reproduction) est assujettie à sa politique d'utilisation que vous pouvez consulter en ligne.

https://apropos.erudit.org/fr/usagers/politique-dutilisation/ 


\section{Recensions}

\section{Book Reviews}

Industrial Relations: The Economy and Society

by John GODARD, Whitby, Ontario, McGraw Hill Ryerson, 1993, 548 p., ISBN 0-07-551337-4.

John Godard's Industrial Relations: The Economy and Society provides a compelling, original and refreshing examination of Canadian industrial relations as well as offering a different paradigm for conceptualizing the field of industrial relations. This ambitious, indeed brazen, work targets two audiences. It is written for industrial relations academics, whose field has been plagued by stagnation, isolation and erosion, and their students who need a textbook to make the field comprehensible. The author does not shrink from using the appellation "industrial relations" for a field which he sees as addressing the superior-subordinate work relationship in non-unionized and unionized organizations.

First among its four goals, the book seeks to broaden the field's mainstream with respect to the areas it embraces and perspectives it reflects. It does not flee the field's roots but builds upon them. Institutional basics, i.e. history, the nature of the parties and their roles, levels at which they interact, role of law, union impact, collective bargaining and dispute resolution, are addressed in adequate but not the off-putting detail which can characterize industrial relations texts. It reflects an impressive grasp of a wide expanse of classic and current literature and capacity to integrate that which has not been within the traditional industrial relations ambit. Two chapters are devoted to an examination of management theory, policy and practice pertaining to industrial relations. Although there is no discussion of managerial prerogative, the chapters reflect a profound awareness of the need for a deeper understanding of management.

The book develops ideas and themes which it integrates throughout. It avoids inundating the reader with a torrent of facts. The chapters are not discrete but interconnect and reinforce each other. Avoiding advocacy, the book develops, contexturalizes and critically evaluates a continuum of five perspectives, each of which offers unique and useful contributions to a balanced view of industrial relations. The book calls for broad pluralistic dialogue and analysis among the radical, liberal reformist, orthodox pluralist (institutionalist), managerialist and neoclassical perspectives. The author contends that no one perspective resolves the conflicts inherent in industrial relations. Rather, the field is heir to a multi-ideological as well as multi-disciplinary dynamism. These realizations do not stop the author from trying to square the circle by proffering his own solution to the inherent conflict between labour and capital. Godard advocates employee ownership.

The focus upon perspectives for viewing the field makes it a useful way to introduce students to the ideas underpinning IR as well as HRM. It enables them to contextualize ideas, events, people and organizations that might not conform to their personal values. 
Students are compelled to examine their personal values alongside systematically presented alternatives. The approach can be liberating to conflicted institutionalists feeling trapped by the field's seeming implosion. It reminds readers of the legitimacy and utility of options. The book celebrates the richness of industrial relations theory.

Second, Godard aspires to move the industrial relations mainstream closer to the sociology and political economy literature. He discusses the grand theorists (Marx, Durkheim and Weber) tying them into contemporary theory (e.g. post-bureaucracy and regulation theories), practice and experience. Bruce Kaufman's The Origins and Evolutions of the Field of Industrial Relations in the United States advocates broadening the industrial relations focus to include "external" factors. Godard uses such an approach, expanding the range of debate and analysis by integrating issues of social control, income, class, social mobility and the role of the state. The move represents an attempt to reinvigorate longstanding, but atrophied, multidisciplinary links. The author's handling of these subjects is approachable, interesting and a compelling example of expanding the field's horizons.

Godard's third and no less ambitious objective is to foster a pedagogy in which instructors act more as discussion leaders and lecture less. The presumption is that the student who understands the book's contents will have a sound conceptual knowledge of industrial relations. The instructor's job is to create an environment wherein students can explore and become conversant with it. This may imply a substantial investment by the instructor who is called upon to reconceive his/her teaching methods, adopt a different perspective of the field and break the highly conceptual material into bits which students can digest.

Speaking as one who applied the author's prescription to a mandatory introductory undergratuate class, I can attest to the results. Students' found the experience more edifying and interesting than the traditional lecture method. They examined and formulated their own views based upon clear choices. Students did not react dismissively to subject matter which they perceived as being biased or a least suspect. They were forced to think. This method is a good vehicle for introducing students to concepts underlying both HRM and IR. The change of material and pedagogy was liberating. Moreover, by broadening the course's focus to encompass the employment relationship within the context of political economy, the mandatory industrial relations class survived a college curriculum as a core offering. The book has obvious utility for graduate students.

Finally, the book aspires to changing IR practice in Canada by affecting the thinking of academics, policy makers and practitioners. The book has the potential for opening minds. That is the first step to changing practice.

This is an important book for students of the field to examine as a prescription for the field's malaise and what and how we teach. It offers challenges, even a lifeline, which merit the attention of industrial relations scholars in Canada and the U.S.

KURT WETZEL University of Saskatchewan 